\title{
Analisis Kemampuan Pemahaman Konsep Matematis Siswa di Era New Normal
}

\author{
Serli Restu Fauziah ${ }^{*}$, Sefna Rismen², Lita Lovia ${ }^{3}$ \\ 1,2,3TKIP PGRI Sumatera Barat, Padang, Indonesia \\ ${ }^{*}$ Corresponding Author
}

\begin{tabular}{l} 
Informasi Artikel \\
\hline DiterimaRedaksi: 1 Februari 202l \\
RevisiAkhir: 5 Maret 2021 \\
Diterbitkan Online: 31 Juni 2021 \\
Kata Kunci \\
\hline Pembelajaran Matematika \\
Kemampuan Pemahaman Konsep \\
Matematis siswa \\
Di Era New Normal \\
Korespondensi \\
\hline E-mail: serlirestufauziah@gmail.com
\end{tabular}

E-mail: serlirestufauziah@gmail.com

\begin{abstract}
A B S T R A C T
This research is motivated by the low ability of students to understand mathematical concepts when learning has been done online for almost a year at home, which is now back again face to face at school with less study time than usual. The purpose of this study was to find out how the students' mathematical concept understanding ability in the new normal era of class $X$ science at Madrasah Aliyah Swasta (MAS) Lubuk Malako, South Solok Regency. The research method used is descriptive method using a quantitative approach. The sampling technique used purposive sampling with a sample of 18 students. The instrument used to collect data was in the form of a student's mathematical concept understanding ability test and interviews. The test results were analyzed based on the assessment criteria of high, medium, low, and very low. The results showed that the ability to understand mathematical concepts of students in the new normal era of class $X$ science was still relatively low with a percentage of $39 \%$, namely indicators of restating concepts, presenting concepts in various representations, and relating various mathematical concepts internally or externally. While the criteria are high with a percentage of $17 \%$, moderate with a percentage of $33 \%$, and very low with a percentage of $11 \%$.
\end{abstract}

Penelitian ini dilatarbelakangi oleh rendahnya kemampuan pemahaman konsep matematis siswa disaat belajar yang pernah dilakukan secara online hampir satu tahun di rumah yang sekarang kembali lagi tatap muka di sekolah dengan waktu belajar yag lebih sedikit dari biasanya. Tujuan penelitian ini untuk mengetahui bagaimana kemampuan pemahaman konsep matematis siswa di era new normal kelas X IPA di Madrasah Aliyah Swasta (MAS) Lubuk Malako Kabupaten Solok Selatan. Metode peelitian yang digunakan adalah metode deskriptif dengan menggunakan pendekatan kuantitatif. Teknik pengambilan sampel menggunakan purposive sampling dengan banyak sampel 18 siswa. Instrumen yang digunakan untuk megumpulkan data berupa tes kemampuan pemahaman konsep matematis siswa dan wawancara. Hasil tes dianalisis berdasarkan kriteria penilaian yang tinggi, sedang, rendah, dan sangat rendah. Hasil penelitian menunjukkan bahwa kemampuan pemahaman konsep matematis siswa di era new normal kelas X IPA masih tergolong rendah dengan persentase 39\% yaitu indikator menyatakan ulang konsep, menyajikan konsep dalam berbagai representasi, dan mengaitkan berbagai konsep matematika secara internal atau eksternal. Sedangkan kriteria tinggi dengan presentase $17 \%$, sedang dengan presentase $33 \%$, dan sangat rendah dengan presentase $11 \%$.

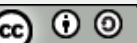

02021 by the authors. Submitted for possible open access publication under the terms and conditions of the Creative Commons Attribution-ShareAlike 4.0 International License-(CC-BY-SA) (https://creativecommons.org/licenses/by-sa/4.0/)

\section{Pendahuluan}

Pembelajaran merupakan upaya yang menciptakan kondisi belajar yang yang dapat memaksimalkan siswa dalam mengikuti proses pembelajaran. [7] menyatakan bahwa "Pembelajaran adalah upaya guru untuk mendorong siswa atau memfasilitasi siswa belajar serta peran guru sebagai fasilitator untuk mengkontruksikan pengetahuannya”. Selanjutnya [8] menyatakan bahwa "pembelajaran merupakan suatu proses dimana informasi tidak hanya berasal dari guru melainkan juga dapat berasal dari peserta didik". Berdasarkan pernyataan tersebut maka pembelajaran harus melibatkan kegiatan dan tindakan yang harus dilakukan untuk mencapai hasil belajar yang baik nantinya. Salah satu pembelajaran yang dilakukan tersebut adalah matematika.

Matematika merupakan salah satu mata pelajaran yang berfugsi mengembagkan kemampuan menghitung, mengukur dan menggunakan rumus matematika yang dapat diaplikasikan dalam kehidupan. Matematika di sekolah mempunyai peranan yang cukup besar dalam kemampuan berpikir dalam memecahkan masalah di kehidupan sehari-hari. Menurut Kartika [5], matematika merupakan 
salah satu cabang yang dapat merubah pola pikir manusia sampai ke masa modern yang berlandaskan teknologi informasi dan komuikasi, sehingga berfungsi mengembangkan kemampuan menghitung, mengukur, dan menggunakan rumus matematika yang dapat diaplikasikan dalam kehidupan. [10] menyatakan bahwa "matematika merupakan ilmu pengetahuan tentang pola dan hubungan yang pembuktiannya bersifat logis dan terbentuk sebagai hasil pemikiran manusia yang berhubungan dengan ide, proses, dan penalaran yang berguna untuk membantu manusia dalam memahami dan menguasai masalah sosial, ekonomi, dan alam".

Pembelajaran matematika sangatlah penting, karena dalam kehidupan sehari-hari tidak dapat terlepas dari penggunaan matematika mulai dari masalah sederhana sampai masalah yang rumit. Pembelajaran matematika siswa diharapkan bukan hanya membuat catatan tetapi mampu menangkap makna dari pembelajaran yang diberikan guru. [1] meyatakan bahwa Pembelajaran matematika merupakan upaya guru dalam proses pembelajaran dengan memperhatikan pemahaman siswa tentang matematika agar memperoleh pemahaman matematika dengan baik".

Pembelajaran matematika di sekolah tidak hanya membuat catatan apa yang sudah dijelaskan oleh guru, tetapi siswa mampu menyimpan maksud dan makna dari pembelajaran yang diberikan guru. Dalam pembelajaran matematika siswa dituntut untuk mengerti mengenai definisi, cara pemecahan masalah, serta pengoperasian matematika secara benar. Ketika siswa memiliki pemahaman konsep yang benar, maka hal tersebut akan menjadi bekal untuk mempelajari matematika pada jenjang pendidikan lebih tinggi [6].

Pemahaman konsep sangat penting dimiliki oleh siswa sehingga proses belajar yang dialami siswa tidak hanya sekedar menghafal dan menjawab soal-soal latihan yang diberikan guru. Jika siswa hanya menghapal tanpa megaitkan konsep dengan konsep lainnya makaproses atau hasil belajar siswa tidak akan bermakna. [6] mengemukakan bahwa "Agar guru membiasakan siswa untuk menyajikan konsep ke berbagai bentuk representasi matematika saat proses pembelajaran dan memberi kesempatan kepada siswa untuk dapat mengaplikasika konsep yang dalam menyelesaikan masalah secara benar dan sistematis".

Menurut [10], "Pemahaman konsep berarti mengerti benar tentang konsep matematika, yaitu siswa dapat menafsirkan dan meyimpulkan suatu konsep matematika berdasarkan pembentukan pengetahuannya sendiri, bukan sekedar menghapal". Pada kenyataannya sampai sekarang siswa hanya menghapal rumus tidak memahami darimana datangnya rumus tersebut. Sehigga siswa tidak dapat mengerjakan soal yang sedikit berbeda dari contoh yang diberikan guru, siswa juga mengalami kesulitan dalam memahami soal. Penelitian [10] menemukan bahwa "pemahaman konsep matematis siswa merupakan suatu kemampuan dasar yang harus dimiliki oleh siswa, dimana siswa mampu megklasifikasikan, menyajikan, menyatakan, menghitung, serta menjelaskan kembali suatu materi denga lebih sederhana akan tetapi tetap akurat dan tepat sehigga lebih mudah dipahami”.

Berdasarkan hasil wawancara yang dilakukan bersama guru di Madrasah Aliyah Swasta (MAS) Lubuk Malako Kabupaten Solok Selatan ditemukan permasalahan yaitu masih banyak siswa yang mempunyai kemampuan pemahaman konsep yang rendah. Rendahnya pemahaman konsep siswa salah satu masalahnya adalah kurangya waktu proses pembelajaran yang biasanya 45 menit per satu jam pelajaran sekarang sudah menjadi 25 menit per satu jam pelajara. Waktu yang sedikit tersebut harus dimaksimalkan oleh guru untuk menjelaskan materi sekaligus membuat siswa tersebut bisa paham dengan materi yang disampaikanya. Belum sepenuhnya paham siswa dengan materi tapi guru harus lanjut denga materi selanjutnya, karena guru harus selesai menjelaskan materi sesuai dengan rancangan proses pembelajaran yang sudah dibuat. Waktu yang sedikit tersebut siswa juga ada yang tidak memperhatikan penjelasana guru, sehingga siswa tidak paham dengan materi yang disampaikan.

Terdapat beberapa faktor-faktor yang mempengaruhi pemahaman konsep matematis siswa, menurut Ngalim dalam [10] dijelaskan bahwa "beberapa faktor yang dapat mempengaruhi keberhasilan siswa dalam mempelajari matematika, yakni : (1) faktor yang ada pada diri siswa itu sendiri, adapun yang termasuk kedalam faktor tersebut antara lain kematangan atau pertumbuhan kecerdasan, latihan, 
motivasi, dan faktor pribadi. (2) faktor yang ada diluar individu, adapun faktor ini dapat dikatakan dengan faktor sosial". Dapat disimpulkan bahwa faktor yang bisa menigkatkan pemahaman konsep matematis adalah lingkungan sekitar, orang lain, keluarga, teman, dan dari diri pribadi siswa tersebut.

Tujuan dari penelitian ini adalah untuk menganalisis bagaimana kemampuan pemahaman konsep matematis siswa di era new normal kelas X IPA di Madrasah Aliyah Swasta (MAS) Lubuk Malako Kabupaten Solok Selatan. Manfaat dari penelitian ini ialah bagi guru sebagai pedoman dalam meningkatkan kemampuan pemahaman konsep matematis siswa dalam mengajar matematika dan bagi peneliti lain sebagai bahan untuk perkembangan penelitian berikutnya untuk mengetahui bagaimana kemampuan pemahaman konsep matematis siswa terhadap pembelajaran matematika.

Penelitian yang relevan dengan penelitian yang akan dilakukan adalah Penelitian Vivi Darmawanti tahun 2020 dengan judul Analisis Kemampuan Pemahaman Konsep Matematika Ditinjau dari Kemandirian Belajar Peserta Didik Kelas VIII pada Materi Sistem Persamaan Linear Dua Variabel (SPLDV). Hasil penelitian menunjukkan bahwa peserta didik dengan kemandirian belajar tinggi memiliki kemampuan pemahaman konsep matematis yang kurang dibandingkan peserta didik dengan kemandirian belajar sedang dan rendah. Hal ini menunjukkan bahwa kemandirian belajar tidak mempengaruhi kemampuan pemahaman konsep matematis peserta didik. Selanjutnya penelitian yang relevan lainnya adalah penelitian Solikhatun Marfuah tahun 2020 dengan judul Analisis Kemandirian Belajar Siswa dalam Pembelajaran Matematika Secara Online di SMP Negeri 1 Cilongok. Hasil penelitian ini menunjukkan bahwa kemandirian belajar siswa dalam pembelajaran matematika secara online berada pada kategori tinggi pada lima indikator, yaitu inisiatif belajar, mendapatkan target atau tujuan, memandang kesulitan sebagai tantangan, memilih dan menerapkan strategi belajar, serta mengevaluasi proses hasil belajar. Pada Indikator mendiagnosa kebutuhan belajar, memanfaatkan dan mencari sumber yang relevan, serta self efficacy siswa berada pada kategori sangat tinggi.

Berdasarkan permasalahan yang terdapat pada saat wawancara dan hasil penelitian sebelumnya maka untuk mengetahui bagaimana kemampuan siswa lebih lanjut mengenai kemamapuan pemahaman konsep siswa maka dilakukan penelitian dengan judul "Analisis Kemampuan Pemahaman Konsep Matematis Siswa di Era New Normal Kelas X IPA”.

\section{Metode Penelitian}

Penelitian dilaksanakan pada tanggal 14 - 20 April 2021 semester genap tahun pelajaran 2020/2021 di kelas X IPA Madrasah Aliyah Swasta (MAS) Lubuk Malako Kabupaten Solok Selatan. Metode penelitian dalam penelitian ini adalah survai deskriptif kuantitatif. Penelitian deskriptif kuatitatif adalah penelitian yang mendeskripsikan hasil penelitian dengan angka. Sampel dalam penelitian ini adalah kelas X IPA Madrasah Aliyah Swasta (MAS) Lubuk Malako Kabupaten Solok Selatan. Instrume penelitian dalam penelitian ini adalah:

\subsection{Tes Kemampuan Pemahaman Konsep Matematis}

Tes bertujuan untuk mengukur pemahaman konsep matematis siswa dalam menjawab persoalan matematika yang berisi materi sesuai dengan indikator pemahaman konsep. Indikator yang digunakan adalah indikator menurut penelitian [10], yaitu (a) Menyatakan ulang konsep yang telah dipelajari. (b). Mengklarifikasikan objek-objek berdasarkan konsep matematis. (c). Menerapkan konsep secara algoritma. (d) Memberikan contoh atau kontra contoh dari konsep yang dipelajari. (e) Menyajikan konsep dalam berbagai representasi. (f) Mengaitkan berbagai konsep matematis secara internal atau eksternal.

Langkah-langkah penyusunan perangkat tes adalah menyusun soal tes dan validitas tes. Validitas tes yang digunakan validasi formulasi Aiken's V (1985: 173) dalam (Hendryadi, 2017) yang didasarkan pada hasil penilaian dari ahli matematika yaitu 2 dosen pembimbing dan 1 guru matematika. Langkah- 
langkah yang digunakan dalam mengumpulkan data ialah menyiapkan soal tes, membagikan soal tes kepada siswa, mengawasi siswa dalam mengerjakan soal, mengumpulkan hasil tes, memeriksa dan mengevaluasi hasil tes, serta meganalisis hasil tes. Teknik analisis data menggunakan rubrik analitik skala 4. Data dianalisis menggunakan rumus presentase sebagai berikut:

$$
\text { Persentase Skor }=\frac{\text { jumlah skor yang diperoleh }}{\text { jumlah skor maksimum }} \times 100 \%
$$

Untuk mengetahui persentase kemampuan pemahaman konsep matematis siswa menggunakan pengelompokkan kategori sebagai berikut:

Tabel 1. Kategori Hasil Persentase Kemampuan Pemahaman Konsep Matematis

\begin{tabular}{cc}
\hline Kategori & Persentase (\%) \\
\hline Tinggi & $75 \leq \mathrm{P} \leq 100$ \\
Sedang & $50 \leq \mathrm{P}<75$ \\
Rendah & $25 \leq \mathrm{P}<50$ \\
Sangat Rendah & $0 \leq \mathrm{P}<25$ \\
\hline
\end{tabular}

Sumber : Istikomah (2016)

\subsection{Wawancara}

Wawancara dilakukan setelah memberikan tes sesuai dengan pedoman wawancara. Tujuan melakukan wawancara adalah untuk mengumpulkan informasi mengenai sejauh mana kemampuan pemahaman konsep matematis yang dimiliki oleh siswa yang tidak diamati secara langsung dan untuk mengetahui bagaimana kemampuan pemahaman konsep matematis siswa. Hasil dari wawancara akan dianalisis dengan hasil tes yang telah diberikan kepada siswa sebelumnya. Wawancara dilakukan dengan 8 siswa terdiri dari 4 siswa yang berkategori tinggi, sedang, rendah, dan sangat rendah.

\section{Hasil dan Pembahasan}

Hasil tes kemampuan pemahaman konsep matematis yang telah diselesaikan siswa dan diidentifikasi dengan tingkat kemampuan pemahaman konsep matematis dapat diperoleh kelompok kemampuan siswa berdasarkan kriteria tinggi, sedang, rendah dan sangat rendah. Hasil penelitian yang telah dilakukan pada 18 siswa dengan memberikan 6 butir soal yang mencakup indikator pemahaman konsep yang telah diselesaikan siswa diperoleh data kemampuan pemahaman konsep matematis siswa seperti Tabel 1 dibawah ini.

Tabel 2. Hasil Perhitungan Tes Kemampuan Pemahaman Konsep

\begin{tabular}{lcccc}
\hline No & Siswa & Total Skor & Hasil (\%) & Kategori \\
\hline $\mathbf{1}$ & ARP & 50 & $51 \%$ & Sedang \\
$\mathbf{2}$ & DA & 47 & $47 \%$ & Rendah \\
$\mathbf{3}$ & GW & 72 & $73 \%$ & Sedang \\
$\mathbf{4}$ & LHV & 20 & $20 \%$ & Sangat Rendah \\
$\mathbf{5}$ & MW & 34 & $34 \%$ & Rendah \\
$\mathbf{6}$ & MF & 36 & $36 \%$ & Rendah \\
$\mathbf{7}$ & MM & 40 & $40 \%$ & Rendah \\
$\mathbf{8}$ & NRA & 64 & $65 \%$ & Sedang \\
$\mathbf{9}$ & OS & 50 & $51 \%$ & Sedang \\
$\mathbf{1 0}$ & PY & 49 & $49 \%$ & Rendah \\
$\mathbf{1 1}$ & RF & 30 & $30 \%$ & Rendah \\
$\mathbf{1 2}$ & RI & 86 & $87 \%$ & Tinggi \\
\hline
\end{tabular}




\begin{tabular}{lcllc}
\hline $\mathbf{1 3}$ & R & 20 & $20 \%$ & Sangat Rendah \\
$\mathbf{1 4}$ & ROM & 78 & $79 \%$ & Tinggi \\
$\mathbf{1 5}$ & SY & 78 & $79 \%$ & Tinggi \\
$\mathbf{1 6}$ & UH & 51 & $52 \%$ & Sedang \\
$\mathbf{1 7}$ & WDS & 32 & $32 \%$ & Rendah \\
$\mathbf{1 8}$ & ZA & 54 & $55 \%$ & Sedang \\
\hline
\end{tabular}

\section{Kemampuan Pemahaman Konsep Matematis Siswa Berdasarkan Kriteria Tinggi}

Berdasarkan Tabel 2 diperoleh hasil tes kemampuan pemahaman konsep dari 18 orang siswa terdapat 3 siswa yang berkemampuan tinggi dengan persentase 17\%. Siswa yang berkemampuan tinggi ialah siswa RI, ROM, dan SY. Siswa RI mendapatkan total skor 78 dengan persentase 79\%, dan siswa SY jugamendapatkan total skor 78 dengan persentase $79 \%$. Dari 3 orang siswa yang berkemampuan tinggi dipilih satu orang untuk melakukan wawancara yaitu siswa RI yang mendapatka nilai yaitu $87 \%$. Jadi dapat disimpulkan bahwa hasil perhitungan tes kemampuan pemahaman konsep matematis siswa, siswa ini kurang mampu mengklarifikasikan objek-objek berdasarkan konsep matematis dan memberikan contoh atau kontra contoh dari konsep yang dipelajari. Siswa ini juga mempunyai pemahaman konsep yang lumayan tinggi meskipun belum sepenuhnya tercapai semua indikator pemahaman konsep matematis. Sesuai dengan teori [10] bahwa "pemahaman konsep matematis meliputi menyatakan ulang konsep yang telah dipelajari, mengklarifikasikan objek-objek berdasarkan konsep matematis, menerapkan konsep secara algoritma, memberikan contoh atau kontra contoh dari konsep yang dipelajari, menyajikan konsep dalam berbagai representasi, dan mengaitkan berbagai konsep matematis secara internal atau eksternal". Indikator yang bisa dicapai oleh siswa ini adalah menyatakan ulang konsep, menerapkan konsep secara algoritma, menyajikan konsep dalam berbagai representasi, dan mengaitkan berbagai konsep matematis secara internal/eksternal.

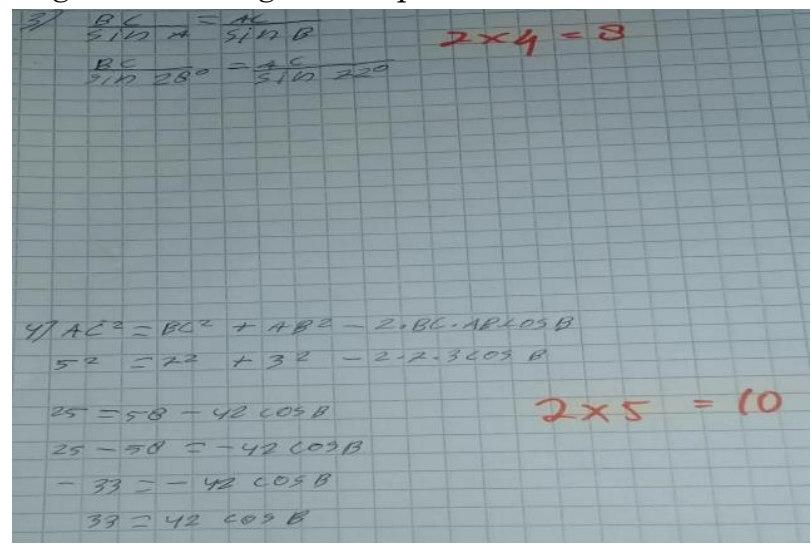

Gambar 1. Hasil Kerja Siswa RI

\section{Kemampuan Pemahaman Konsep Matematis Siswa Berdasarkan Kriteria Sedang}

Berdasarkan Tabel 2 dari 18 orang siswa yang telah mengikuti tes terdapat 6 orang siswa yang termasuk kedalam kelompok kemampuan sedang dengan persentase 33\%. Siswa yang termasuk berkemampuan sedang ialah siswa ARP, GW, NRA, OS, UH,dan ZA. Siswa ARP mendapatkan total skor 50 dengan persentase $51 \%$, siswa GW mendapatkan total skor 72 dengan persentase $73 \%$, siswa NRA medapatkan total skor 64 dengan persentase $65 \%$, siswa OS medapatkan total skor 50 dengan persentase 51\%, siswa UH mendapatkan total skor 50 dengan persentase 51\% juga, dan siswa ZA mendapatkan mendapatkan total skor 54 dengan persentase 55\%. Dari 6 orang siswa yang berkemampuan sedang dipilih satu orang untuk melakukan wawancara yaitu siswa UH yang mendapatkan nilai yaitu $52 \%$. Jadi dapat disimpulkan bahwa siswa ini mempunyai pemahaman konsep yang sedang sehingga belum tercapai semua indikator pemahaman konsep matematis. Terlihat dari 3 soal yang tidak dijawab sepenuhnya dan ada juga soal yang tidak dijawab sama sekali. Sesuai dengan teori [10] bahwa 
"pemahaman konsep matematis meliputi menyatakan ulang konsep yang telah dipelajari, mengklarifikasikan objek-objek berdasarkan konsep matematis, menerapkan konsep secara algoritma, memberikan contoh atau kontra contoh dari konsep yang dipelajari, menyajikan konsep dalam berbagai representasi, dan mengaitkan berbagai konsep matematis secara internal atau eksternal". Indikatot yang bisa dicapai siswa ini adalah menyatakan ulang konsep dan mengklasifikasi objek-objek berdasarkan konsep matematika.

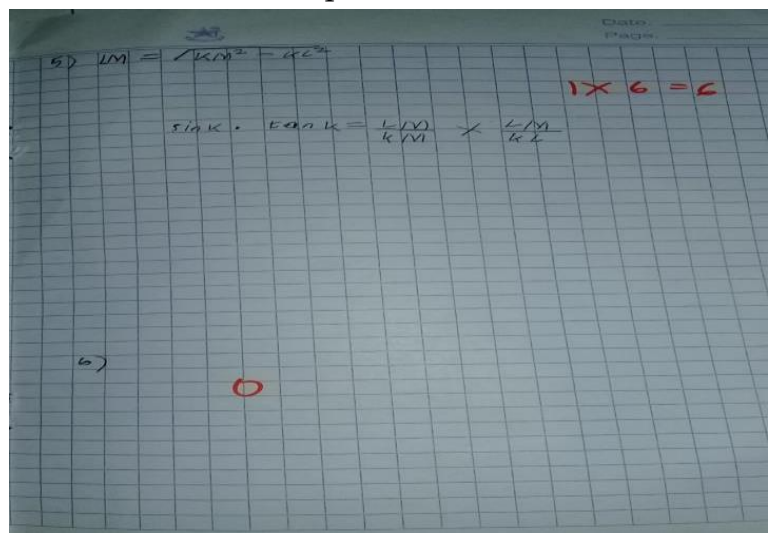

Gambar 2. Hasil Kerja Siswa UH

\section{Kemampuan Pemahaman Konsep Matematis Siswa Berdasarkan Kriteria Rendah}

Berdasarkan Tabel 2 dari 18 orang siswa yang telah mengikuti tes terdapat 7 orang siswa yang termasuk kedalam kelompok kemampuan rendah dengan persentase 39\%. Siswa yang termasuk berkemampuan sedang ialah siswa DA, MW, MF, MM, PY, RF, dan WDS. Siswa DA mendapatkan total skor 47 dengan persentase 47\%, siswa MW medapatkan total skor 34 dengan persentase $34 \%$, siswa MF mendapatkan total skor 36 dengan persentase 36\%, siswa MM mendapatkan total skor 40 dengan persentase 40\%, siswa PY mendapatkan total skor 49 degan persentase $49 \%$, siswa RF mendapatkan total skor 30 dengan persentase 30\%, dan siswa WDS mendapatkan total skor 32 dengan persentase $32 \%$. Dari 7 orang siswa yang berkemampuan rendah dipilih satu orang untuk melakukan wawancara yaitu siswa DA yang mendapatkan nilai yaitu $47 \%$. Jadi dapat disimpulkan bahwa siswa mempunyai kemampuan pemahaman konsep yang rendah sehinggabelum tercapai semua indikator pemahaman konsep matematis. Siswa tidak mampu megklarifikasikan, menyajikan, menyatakan, menghitung, serta menjelaskan kembali suatu materi dengan lebih sederhana. Sesuai dengan teori Darmawanti (2020) bahwa "pemahaman konsep matematis meliputi menyatakan ulang konsep yang telah dipelajari, mengklarifikasikan objek-objek berdasarkan konsep matematis, menerapkan konsep secara algoritma, memberikan contoh atau kontra contoh dari konsep yang dipelajari, menyajikan konsep dalam berbagai representasi, dan mengaitkan berbagai konsep matematis secara internal atau eksternal". Indikator yang bisa dicapai siswa ini hanya menerapkan konsep secara algoritma.

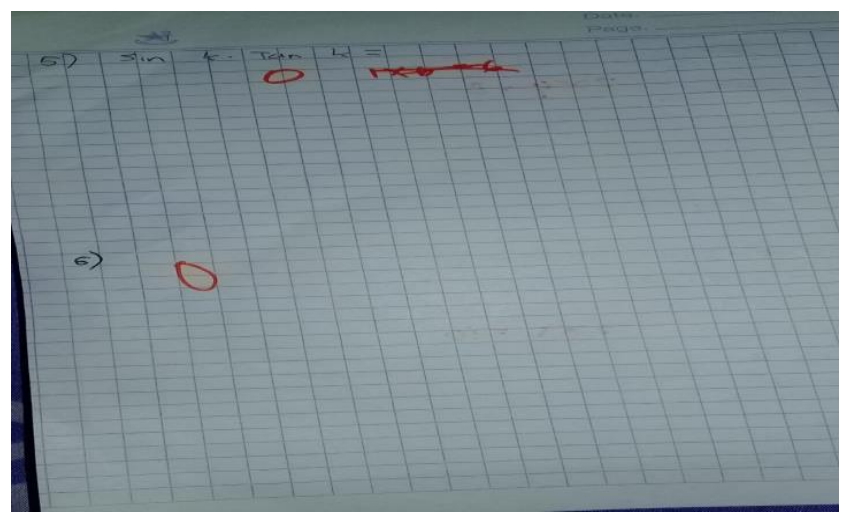

Gambar 3. Hasil Kerja Siswa DA 


\section{Kemampuan Pemahaman Konsep Matematis Siswa Berdasarkan Kriteria Sangat Rendah}

Berdasarkan Tabel 2 dari 18 orang siswa yang telah mengikuti tes terdapat 2 orang siswa yang termasuk kedalam kelompok kemampuan yang sangat rendah dengan persentase $11 \%$. Siswa yang termasuk berkemampuan sangat rendah ialah siswa LHV dan R. Siswa LHV mendapatkan total skor 20 dengan persentase $20 \%$ dan siswa $R$ mendapatkan total skor 20 dengan persentase $20 \%$ juga. Dari 2 orang siswa yang berkemampuan sangat rendah dipilih satu orang untuk melakukan wawancara yaitu siswa $\mathrm{R}$ yang mendapatkan nilai yaitu $20 \%$. Jadi dapat disimpulkan bahwa siswa tidak mampu memberikan contoh atau kontra contoh dari konsep yang dipelajari, siswa tidak mampu menyajikan konsep dalam berbagai representasi, dan siswa tidak mampu mengaitkan berbagai konsep matematis secara internal atau eksternal. Sesuai dengan teori [10] bahwa "pemahaman konsep matematis meliputi menyatakan ulang konsep yang telah dipelajari, mengklarifikasikan objek-objek berdasarkan konsep matematis, menerapkan konsep secara algoritma, memberikan contoh atau kontra contoh dari konsep yang dipelajari, menyajikan konsep dalam berbagai representasi, dan mengaitkan berbagai konsep matematis secara internal atau eksternal". Berdasarkan teori tersebut siswa ini memiliki pemahaman konsep yang sangat rendah sehingga tidak tercapai semua indikator pemahaman konsep matematis.

\section{Kesimpulan}

Berdasarkan dari hasil analisis data dan pembahasan yang telah dilakukan dapat disimpulkan bahwa kemampuan pemahaman konsep matematis siswa kelas X IPA Madrasah Aliyah Swasta (MAS) Lubuk Malako Kabupaten Solok Selatan berdasarkan 4 kriteria kemampuan pemahaman konsep matematis siswa yag terdiri dari tinggi, sedang, rendah, dan sangat rendah dapat disimpulkan bahwa kemampuan pemahaman konsep matematis siswa di era new normal kelas X IPA masih tergolong rendah dengan persentase 39\% sehingga masih banyak siswa yang belum paham dengan konsep pembelajaran matematika. Siswa yang memiliki pemahaman tinggi yaitu siswa yang memiliki hasil persentase pemahaman antara $75 \%-100 \%$. Siswa yang memiliki pemahaman sedang yaitu siswa yang memiliki hasil persentase pemahaman antara 50\% sampai kurang dari $75 \%$. Siswa yang memiliki pemahaman rendah yaitu siswa yang memiliki hasil persentase pemahaman antara $25 \%$ sampai kurang dari $50 \%$. Siswa yang memiliki pemahaman sangat rendah yaitu siswa yang memiliki hasil persentase pemahaman antara $0 \%$ sampai kurang dari $25 \%$.

\section{Daftar Pustaka}

[1] Astuti, S. (2019). Analisis Kemampuan Pemahaman Konsep Matematis Siswa Kelas XI MIPA 3 SMAN 2 Lubuk Basung (pp. 1-96). STKIP PGRI Sumatera Barat.

[2] Darmawanti, V. (2020). Analisis Kemampuan Pemahaman Konsep Matematis Ditinjau dari Kemandirian Belajar Peserta Didik Kelas VIII pada Materi Sistem Persamaan Linear Dua Variabel (SPLDV). Uin Suska Riau, 1-227.

[3] Hendryadi. (2017). VALIDITAS ISI : TAHAP AWAL PENGEMBANGAN KUESIONER. Jurnal Riset Manajemen Dan Bisnis (JRMB) Fakultas Ekonomi UNIAT, 2(2), 169-178.

[4] Istikomah. (2016). Kemampuan pemahaman konsep matematis mahasiswa melalui pendekatan pembelajaran saintifik dalam perkuliahan aljabar matrik. Universitas PGRI Yohyakarta, 1-6.

[5] Kartika, Y., Program, M., Magister, S., Matematika, P., \& Riau, U. (2018). Analisis kemampuan pemahaman konsep matematis peserta didik kelas vii smp pada materi bentuk aljabar. Jurnal Pendidikan Tambusi, 2(58), 777-785.

[6] Melinda. (2018). Analisis Kemampuan Pemahaman Konsep Matematika Mahasiswa Pgsd 
Stkip Persada Khatulistiwa Sintang. Jurnal Pendidikan Dasar Perkhasa, 4(April), 91-105.

[7] Muslim, E. (2019). Analisis Kemampuan Literasi Matematika Ditinjau dari Gaya Belajar Siswa Kelas XII MIA 3 SMA Negeri 1 Lubuk Basung (pp. 1-136). STKIP PGRI Sumatera Barat.

[8] Shofwah, N., Nindiasari, H., \& Syamsuri. (2020). Analisis Kemandirian Belajar Siswa Berdasarkan Gender di MTs Al-Khairiyah Pakuncen Serang Banten. Jurnal Penelitian Dan Pengajaran Matematika, 2(2), 163-176.

[9] Solikhatun Marfu'ah. (2020). Analisis Kemandirian Belajar Siswa dalam Pembelajaran Matematika Secara Online Di SMP Negeri 1 Cilongok PROGRAM STUDI TADRIS MATEMATIKA. Institut Agama Islam Negeri Purwokerto.

[10] Syarifah, L. L. (2017). Analisis kemampuan pemahaman matematis pada mata kuliah pembelajaran matematika sma ii. JPPM, 10(2), 57-71.

[11] Yufentya, W. E., Roza, Y., Riau, U., \& Konsep, K. P. (2019). Analisis Kemampuan Pemahaman Konsep Siswa Kelas VIII SMP pada Materi Lingkaran. Jurnal Matematika, 2(3), 197-202. 